\title{
ELK4 wt Allele
}

National Cancer Institute

\section{Source}

National Cancer Institute. ELK4 wt Allele. NCI Thesaurus. Code C97477.

Human ELK4 wild-type allele is located in the vicinity of $1 \mathrm{q} 32$ and is approximately $25 \mathrm{~kb}$ in length. This allele, which encodes ETS domain-containing protein Elk-4, plays a role in the modulation of transcription. A chromosomal aberration involving this gene and the SLC45A3 gene may be associated with prostate cancer. 